\title{
CONTRIBUTION TO THE BIOLOGICAL AND SEROLOGICAL STUDY OF B. ABORTUS EQUI.
}

\author{
Semchi Funmura, Takno Toyoshima and Takgo Sugnaga. \\ (From the Veterinary Laboratory, Ministry of Ayriculture and \\ Forestry, Nishigahara, Tokyo.)
}

(Received for publication January 30, 1926.)

It is a severe shock for horse breeders in our country since years that the infectious abortion prevails in mares. In the course of examining a considerable number of aborted colts and fetal membranes in our laboratory, $R$. abortus egui was demonstrated in some cases but in other cases neither such bacilli nor other bacteria were demonstrated.

It is widely believed, however, that abortion and premature birth could be caused by other bacteria or their toxins.

It has been found in Japan, according to the researches already made, that the abortion in mares has most frequently been caused by the infection of $B$. abortus equi which was demonstrated by several investigators.

For this reason our attention has been directed to the comparative study of $B$. abortus equi of Smith and Kilborne and other organisms of paratyphoid-enteritidis group.

It has long been known that a certain toxic substance is produced in old culture of organisms belonging to the paratyphoid-enteritidis group, but little is known about the toxicity of culture filtrate of $B$. abortus equi. We have demonstrated, however, the presence of toxic substance in a bacteria-free, filtrate of 2-4 weeks old broth culture of this organism, and recognized that any considerable variation in the toxic properties of filtrates derived from broth cultures of other organisms of this group.

We have also found that the toxicity of the filtrate varies with the species of animals; guinea-pigs and mice are most susceptible, rabbits much less and pigeons undetermined.

It was found, moreover, that 3-7 days old culture filtrate of this organism was fatal to guinea-pigs, but the filtrate of $:-4$ weeks old culture was much stronger in toxicity, while that of 
culture of 5 weeks old and upwards exhibited diminished toxicity for both animals. So it may be possible that a filtrate of maximal toxicity can be obtained within the first few weeks of growth.

As regards culture media, it is apparently true that the reaction, whether alkaline or acid, has nothing to do with the the toxic properties of the culture or filmate.

The luxuriant growth is, however, expected in broth medium containing $4 \%$ glycerine or $20 \%$ normal horse serum, and we can always ensure a maximal content of toxic substance in the filtrate of such culture.

It is also noticeable that in the course of cultivation of this organism the increase of degree of $\mathrm{PH}$ is not considerable in the culture in which acid remained continuously for about 4 weeks (PH 5.8-6.6).

The filtrate was injected into the ear vein of most susceptible animals, such as rabbits and guinea-pigs, in doses, of 0.05-1.0 c.c., after a period varying from 30 to 70 minutes followed a series of manifestations, principally dyspnea, weakness particularly of the hind extremities, faltering, diarrhea and finally death, with or without convulsions, or sometimes gradual recovery.

Now, it is important to decide whether we are dealing with split products of the culture medium produced by the growth of the organism or with the culture medium itself. While control injections of sterile uninoculated medium adjusted to $\mathrm{PH} 6.2$ were not effective, the neutralized filtrate of the culture ( $\mathrm{Pr} 7.2$ ) given intravenously in varying doses up to 1.0 c.c. caused the same symptom as mentioned.

Further experiments ,were made to know whether this substance can favor our idea that it is connected with split product.

Most of the guinea-pigs which received the injection of culture filtrate subcutaneously in less than lethal dose resisted the control injection of the toxic filtrate after 12-16 days.

So we believe that this substance seems to have some antigenic properties.

It has been proved by several investigators that under the influence of $B$. abor'us equi some substance is formed in the animal body, the presence of which may be demonstrated by 
serodiagnostic method. Thus, for mare, an agglutination value of $1: 640-5120$ may be considered as positive, in the sense that the animal has been or is infected.

Our knowledge is, however, still far from complete as to whether the mentioned antibody may remain for months and even years in the blood of animal after infection, or after abortion, or even in the state of complete recovery.

We have had no cases to examine the variation of such antibody in the naturally infected mare. But, in two rabbits (A and $\mathrm{B}$ ) which aborted artificially by the injection of $B$. abortus equi we have obtained some results; namely, every serum showed almost the same decrease in agglutinative titer on the strains of $B$. abortus equi in the course of one year after abortion, as seen in following table:

Table 1.

\begin{tabular}{|c|c|c|c|c|c|c|c|}
\hline $\begin{array}{l}\text { Weeks after } \\
\text { abortion } \\
\text { Dilution } \\
\text { of serum }\end{array}$ & $1-4$ & $5-12$ & $13-23$ & $24-25$ & $26-38$ & $40-46$ & $47-51$ \\
\hline $\begin{array}{l}1: 5130 \\
1: 2560 \\
1: 1280 \\
1: 640 \\
1: 330 \\
1: 160 \\
1: 80 \\
1: 40 \\
1: 30\end{array}$ & A, B & $A, B$ & $A, B$ & $\mathrm{~A}^{\mathrm{I}}$ & $A, B$ & $\mathbf{A}^{\mathbf{B}}$ & $\mathrm{A}, \mathrm{B}$ \\
\hline
\end{tabular}

It must be noted here that the normal rabbit has yielded serum which had no definite agglutinative action above $1: 20$.

So far as can be gathered from the experiments regarding agglutinative reactions, there are both cultural and serological differences between the bacilli isolated from infectious abortion in mares and other paratyphoid bacilli.

From our repeated serological tests it may be said that the equine strains can distinctly separated from $B$. paratyphosus $B, B$. enteritidis and B. taphi murium. 
Table 2.

\begin{tabular}{|c|c|c|c|c|}
\hline $\begin{array}{c}\text { Kind of } \\
\text { antigen } \\
\text { serum }\end{array}$ & $\begin{array}{l}\text { B. abortus } \\
\text { equi }\end{array}$ & $\begin{array}{l}\text { B. para } \\
\text { typhosus }\end{array}$ & $\begin{array}{l}\text { B. typhi } \\
\text { murium }\end{array}$ & $\begin{array}{l}\text { B. enteritidis } \\
\text { (Giirtner) }\end{array}$ \\
\hline $\begin{array}{l}\text { B. abortus equi } \\
\text { inmune serum of } \\
\text { rabbit }\end{array}$ & $1: 10,240$ & $1: 320$ & $1: 320$ & $1: 40$ \\
\hline $\begin{array}{l}\text { B. paratyphosus } \mathbf{B} \\
\text { inmune serum of } \\
\text { rabbit }\end{array}$ & $1: 1,280$ & $1: 10,240$ & $1: 1,280$ & $1: 160$ \\
\hline $\begin{array}{c}\text { B. typhi murium } \\
\text { immune serum of } \\
\text { rabbit }\end{array}$ & $1 ; 2,560$ & $1: 2,560$ & $1: 10,240$ & $1 ; 80$ \\
\hline $\begin{array}{l}\text { B. enteritidis } \\
\text { Gürtner } \\
\text { immune serum of } \\
\text { rabbit }\end{array}$ & $1: 640$ & $1: 160$ & $1: 160$ & $1: 5,120$ \\
\hline
\end{tabular}

In the cultural reactions, the dry, membranous and brittle growth on slanted agar noted by several observers has been manifested on every transfer. However, there have been some strains of this organism in which the cultural distinction was not observed on the agar, and they grew as organisms of the paratyphoid-enteritidis group.

By way of this experiment it has been found that their characteristic membranous growth depends upon the hydrogen ion concentration in culture medium.

Taking this matter into consideration, we can say that $\mathrm{PH}$ 6.0-8.4 of medium is most suitable for the characteristic growth of this organism, $P_{H} 9.0$ less advisable and no growth may be observed in $\mathrm{PH}_{\mathbf{H}} \mathbf{9 . 6}$ or more. Therefore, we can recommend the slant agar containing $4 \%$ glycerine for the characteristic growth of the organism.

\section{SUMMARY}

B. abortus equi can be separated from the various members of the paratyphoid-enteritidis group as a special bacillus and is perhaps the only organism causing abortion in mares. 


\section{馬流產菌ノ生物學的站血清學的㸴究補遺}

藤村誠一豐島武夫末永武夫

（農林省獸没調 查所）

本邦二於ケル馬，流產モ亦泰西ノソレノ如ク其原因多樣二亘ル 人觀アルモ今日制然タルモノ八䍛り B. abortus equi 二因ルモノ. ノミナり

本編、Smith 及 Kilborne 雨氏ノ所謂 B. abortus equi ト他ノぱ らちふす B 菌屬細菌ト 7 生物學的站血清學的二比較研究七ル成績 八概要ナり

著者等ハ先ヅ本菌ノ肉汁培養無菌滤過液中二入他ハぱらちふす $\mathrm{B}$ 菌屬細菌妇寧口强烈二るるもっこ及まう方等二特異中毒症狀 並致死的經過习呈セシムル一種ノ埥性物質ノ溶存セルヨ認メタル モ該毒性八極メラ不定ニシラ培養期間，培養基ノ性，培養基八種 類及培養期間二於ケル培養基ノ水素いを九濃度，變化等二關スル 反復試驗,結果每常同一程度ノモノヨ得ハコト甚ダ困難ナルア知 レシ然レトモ大體二於亏酸性ぐりせりん (4\%) 加肉汁， $2-4$ 週 間培養滤過液八毒性最モ强ク且培養期間中二於ヶル水素いをん濃 度ノ變化モ亦僅微ニシラ 5 週間以上培養ヨ繼續スル時ハ著シク毒 性衰フルモ八如シ而シラ本培養濾過液习以ラ前處置七ルもる もっこ及まうすハ10-16日後二於少致死量 2 倍八濾過液對照泩 射二對シテ殆ント無反應二經過シ或八對照動物二比シ死期入延長 ヨ見タルモノ多シ故二該滤過液中二八免疫元的價值习有スル物質 ノ溶存ズルヨ認容シ得ベシ

次二馬流產菌

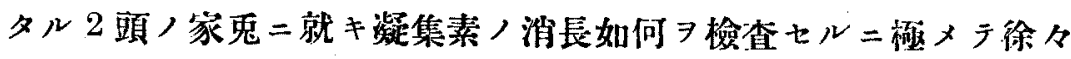
二彪減スルモノニシラ流產當初 1:5120人凝集價ヨ示シタルモ, 
满 1 筒年 經過セル後佾 $1: 160$ ヨ保持スルヨ認メタリ本菌二對 スル家兔，正常凝集價 (最高 $1: 20$ ) ハ殆ント之ヨ認メズ

本菌培養, 乾燥性皺譬形成卜培養基ノ水素いをん濃度, 新舊, 乾濕及焒養分ノ含有量等卜，關係二就テハ明ナラザレトモ發育良 好ナル場合ハ形成モ亦旺盛ニシテぐりせりん加寒天二於テハ普通 寒天培養二比シ遙カニ勝レルが如クぱらちふす B 菌及鼠ちふす 菌二於テ

又 B. abortus equi 及ぱらちふす B 菌屬細菌 ア以テ免疫七ル家 鬼血清 7 用七テ行人ル交叉的凝集反應ノ結果以格段ノ差アリテ本 菌ハ全クばらちふす $\mathrm{B}$ 菌卜別個ノ菌ナリト信ズルヨ可トス 